\title{
Analyzing Regional Geographic Challenges: The Resilience of Chinese Vineyards to Land Degradation Using a Societal and Biophysical Approach
}

\author{
Yang Yu ${ }^{1,2}$ and Jesús Rodrigo-Comino ${ }^{3,4, *(\mathbb{D})}$ \\ 1 School of Soil and Water Conservation, Beijing Forestry University, Qinghua East Road 35, \\ Beijing 100083, China; yangyu@bjfu.edu.cn \\ 2 Jixian National Forest Ecosystem Research Network Station, CNERN, Beijing Forestry University, \\ Beijing 100083, China \\ 3 Soil Erosion and Degradation Research Group, Department of Geography, Valencia University, \\ 46010 Valencia, Spain \\ 4 Department of Physical Geography, Trier University, D-54286 Trier, Germany \\ * Correspondence: jesus.rodrigo@uv.es
}

check for updates

Citation: Yu, Y.; Rodrigo-Comino, J. Analyzing Regional Geographic Challenges: The Resilience of Chinese Vineyards to Land Degradation Using a Societal and Biophysical Approach. Land 2021, 10, 227. https://doi.org/ 10.3390/land10020227

Academic Editor: Vincent Chaplot

Received: 31 January 2021

Accepted: 19 February 2021

Published: 23 February 2021

Publisher's Note: MDPI stays neutral with regard to jurisdictional claims in published maps and institutional affiliations.

Copyright: (c) 2021 by the authors. Licensee MDPI, Basel, Switzerland. This article is an open access article distributed under the terms and conditions of the Creative Commons Attribution (CC BY) license (https:// creativecommons.org/licenses/by/ $4.0 /)$.
Abstract: Land degradation, especially soil erosion, is a societal issue that affects vineyards worldwide, but there are no current investigations that inform specifically about soil erosion rates in Chinese vineyards. In this review, we analyze this problem and the need to avoid irreversible damage to soil and their use from a regional point of view. Information about soil erosion in vineyards has often failed to reach farmers, and we can affirm that to this time, soil erosion in Chinese vineyards has been more of a scientific hypothesis than an agronomic or environmental concern. Two hypotheses can be presented to justify this review: (i) there are no official and scientific investigations on vineyard soil erosion in China as the main topic, and it may be understood that stakeholders do not care about this or (ii) there is a significant lack of information and motivation among farmers, policymakers and wineries concerning the consequences of soil erosion. Therefore, this review proposes a plan to study vineyard soil erosion processes for the first time in China and develop a structured scientific proposal considering different techniques and strategies. To achieve these goals, we present a plan considering previous research on other viticultural regions. We hypothesize that the results of a project from a regional geographic point of view would provide the necessary scientific support to facilitate deriving guidelines for sustainable vineyard development in China. We concluded that after completing this review, we cannot affirm why vine plantations have not received the same attention as other crops or land uses.

Keywords: China; viticultural region; land degradation; regional geographical approach; human issues; solutions

\section{Introduction}

Agricultural areas are among the most vulnerable territories and are affected by soil and water loss [1-4], pollution [5-7] and loss of fertility [8-10] and biodiversity [11-13]. This is especially noticeable in vineyards, where land degradation processes threaten the sustainability and quality of the final product [14-16]. Many European countries (Spain, France, Italy, Portugal and Germany, among others), South Africa, Chile, Australia, the USA and China contain some of the most important viticultural areas in the world [17]. Similar to the semi-arid Mediterranean, there is also a large number of vineyards near longitude $40^{\circ} \mathrm{N}$ in China [18]. For example, the Qingtongxia Jinshawan Winery, Ningxia Hui Autonomous Region (China), which can be observed in Figure 1.

During the last few decades, several studies have confirmed that land degradation due to soil erosion in vineyards is quite high. Historically, this issue has mainly been studied in the Mediterranean [19]. However, there are no current investigations that show 
if soil erosion rates in Chinese vineyards are similarly high, dealing with this topic as the main one. To assess soil degradation and erosion in emergent crops is critical to avoid land degradation processes and favor development strategies to complete the Land Degradation Neutrality challenge raised by the United Nations [20-22].
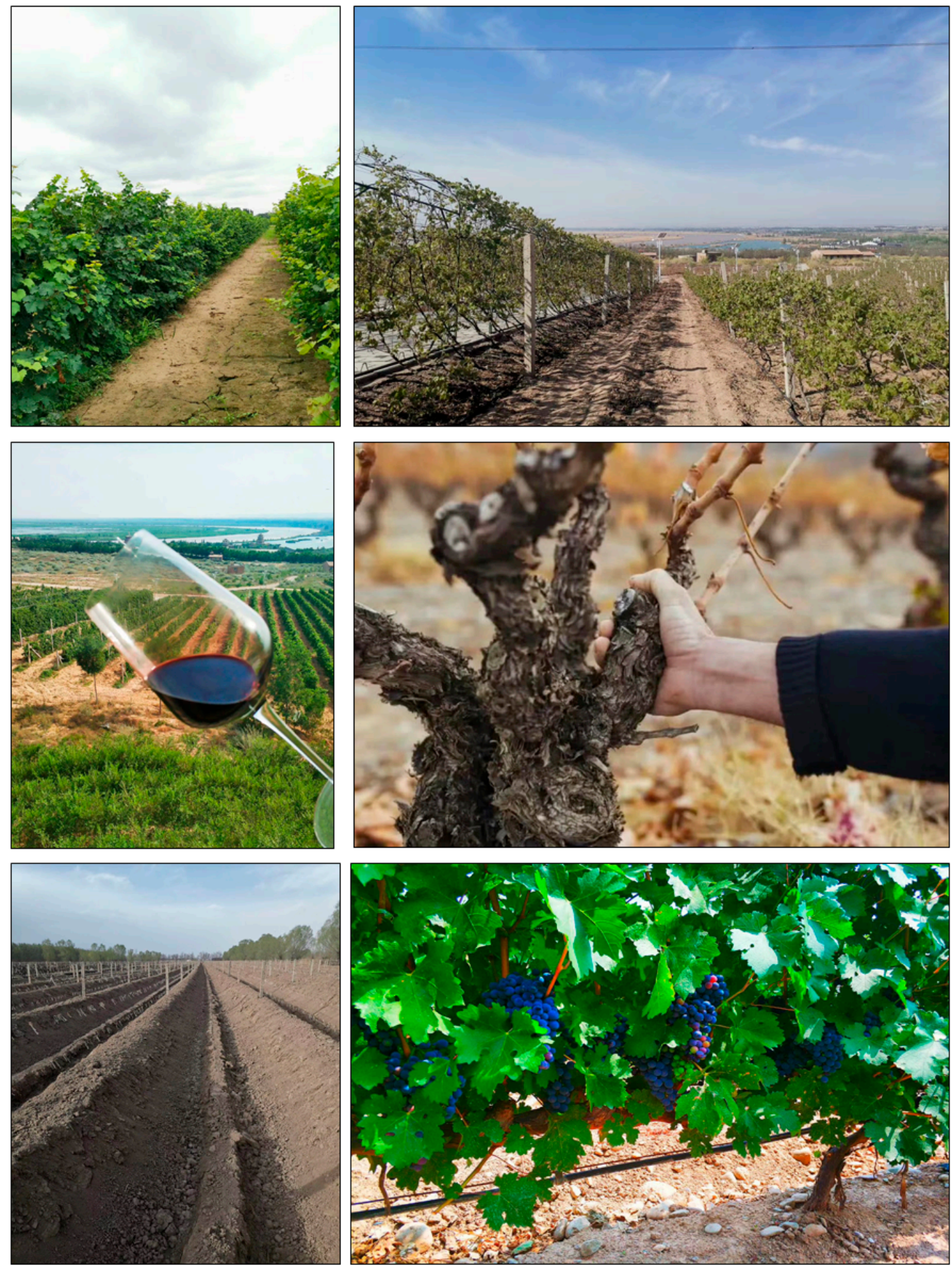

Figure 1. Vineyards of the Qingtongxia Jinshawan Winery, Ningxia Hui Autonomous Region, China. Photographs provided by Assistant Professor Abo Li.

Previous studies in Chinese vineyards mainly focused on vine cultivation, fruit production, pest control and soil nutrient cycles [23,24]. Knowing how soil erosion among 
other processes such as soil water infiltration capacity, microbial diversity or nutrient cycling in Chinese vineyards responds to climatic and anthropogenic impacts should be the foundation for implementing appropriate measures to meet sustainable development goals and would lead to positive consequences for the rural areas, the whole country and the world $[25,26]$.

Soil erosion in vineyards has received considerable attention since the 1960s-1970s, with pioneering studies in Trier (Germany) and Chile beginning with the work of Profs. Richter [27,28] and Merino et al. [29]. Scholars have now formed a strong research foundation regarding soil erosion in vineyards focused on the hillslope and pedon scales. The growth in interest in soil erosion in vineyards has been centered in the Mediterranean basin, mainly in Spain (e.g., [30,31]), Italy (e.g., [32-34]) and France (e.g., [35,36]), where the growth in wine production has been based on the mechanisation of grape production and as a consequence caused an increase in soil erosion, in some cases higher than $50 \mathrm{Mg} \mathrm{ha}^{-1} \mathrm{yr}^{-1}$. Fortunately, other viticultural regions also receive attention from different scholars to analyze other interesting topics, for example, abandonment in Hungary [37,38], tillage in Croatia [39] and soil properties in Turkey [40], highly related to soil erosion rates.

Although China has shown very sensible policies and research related to environmental concerns including soil degradation and desertification processes, in the last two decades [41-43], vineyards expansion and their environmental impact on the soil system has not been covered. Indeed, China has responded to a national land system sustainability emergency via an integrated portfolio of large-scale programs [44]. Sixteen major programs as an integrated sustainability response with a focus on rural land systems for the period since the establishment of the People's Republic of China in 1949 have been developed. Almost every project is related to the prevention and control of land degradation and soil erosion, for example, the Soil and Water Conservation Program-National level from 1983 to 2017 as well as the well-known Grain for Green Program from 1999 to 2020. Viticulture is located in specific regions and under special climatic conditions, which is why it cannot possibly be appropriate to adopt a national program. Although China has published national standards for wine production and quality requirements, there are no specific land management programs for vineyards.

Research in Chinese vineyards is mainly devoted to the interaction of the vines and atmosphere with relevant research on evapotranspiration and grape quality to achieve the best products [23,45-47]. Another interesting research topic is focused on pollution issues [24,48] and bacterial and fungal communities of the soil [49]. However, there are no investigations about the impact of vine plantation, vine cultivation and management on soil erosion and no government programs to avoid the damage caused by accelerated soil erosion rates that have been found in other millennia-old vineyards in Mediterranean areas as the main topic of key articles [16,50].

Land degradation in China has been widely studied, mainly focusing on the variability of climate, parent materials, land uses, water resources, and soils that can be found in this country [51-53]. One of the most studied areas has been the Loess Plateau, which has received special attention from policymakers, stakeholders and scholars [54,55]. Subjects such as the principles of soil erosion, soil and water conservation engineering, gully and rill erosion and desertification-combating sciences have been discussed for steep slopes, depleted fertile soil horizons, deforested areas and intensively cultivated areas, among others. Enormous resources and efforts have been invested in studies on vegetation restoration, ecological hydrology and soil and water conservation [56-58]. The conclusions of these studies can be summarized as follows: (i) the contribution of rainfall, soil and water conservation measurements and vegetation factors to runoff and sediment generation on loess hillslopes; (ii) establishment of different in situ and modeling methods to quantitatively describe multiple factors influencing soil moisture, runoff and soil erosion; (iii) estimation of runoff mitigation by different cover crop root systems; (iv) identification of the effects of terracing and vegetation types on soil conditions after long-term land stabilization 
measures have been implemented and (v) evaluation of soil carbon sequestration in arid and semi-arid degraded lands.

Although land degradation and soil erosion in China has been widely studied, however, there are very few reports on soil erosion in Chinese vineyards, at least, in English in the scientific literature and this reason is currently not known. Therefore, in this review article, we analyze if it is necessary to assess this aspect from a regional point of view to avoid severe soil damage that will need costly restoration programs after one decade. This paper also focuses on which issues need to be developed and control measures adopted in vineyards. Information about soil erosion in vineyards has often failed to reach farmers, and we can affirm that soil erosion in vineyards in China has been more of a scientific hypothesis up to now than an agronomic or environmental concern. We hypothesize two possible reasons: (i) there is no meaningful soil erosion and it is only a scientific issue that stakeholders do not care about or (ii) there is a significant lack of information and motivation among farmers, policymakers, and wineries concerning its consequences. Therefore, we present a review of specific topics to promote the study of soil erosion processes in Chinese vineyards for the first time and develop a common proposal for possible future projects at a regional scale. Furthermore, we infer that local farmers and stakeholders and Chinese scientists that traditionally focused on other crops or forestry and water resources will find a new topic that would bring valuable social and scientific benefits, which will be reflected in a more sustainable agricultural system.

\section{Chinese Vineyards}

China is characterized by large territories with complex climate and soil types. Cultivated vines (Vitis vinifera) were introduced into the Xinjiang Uyghur Autonomous Region around 300 BCE [59]. The mountainous landscape and arid lands did not reduce the contact of this region with the outside world, where there was a cultural center of exchange between East and West on the Silk Road [60]. Grapes have become one of the most widely distributed fruit species in China [61], and almost all Chinese provinces and autonomous regions have commercial vineyards (Figure 2). Within China, between the latitudes of $45^{\circ} \mathrm{N}$ and $25^{\circ} \mathrm{N}$, many unique wineries have become a hotbed for both Chinese and foreign investors [62].

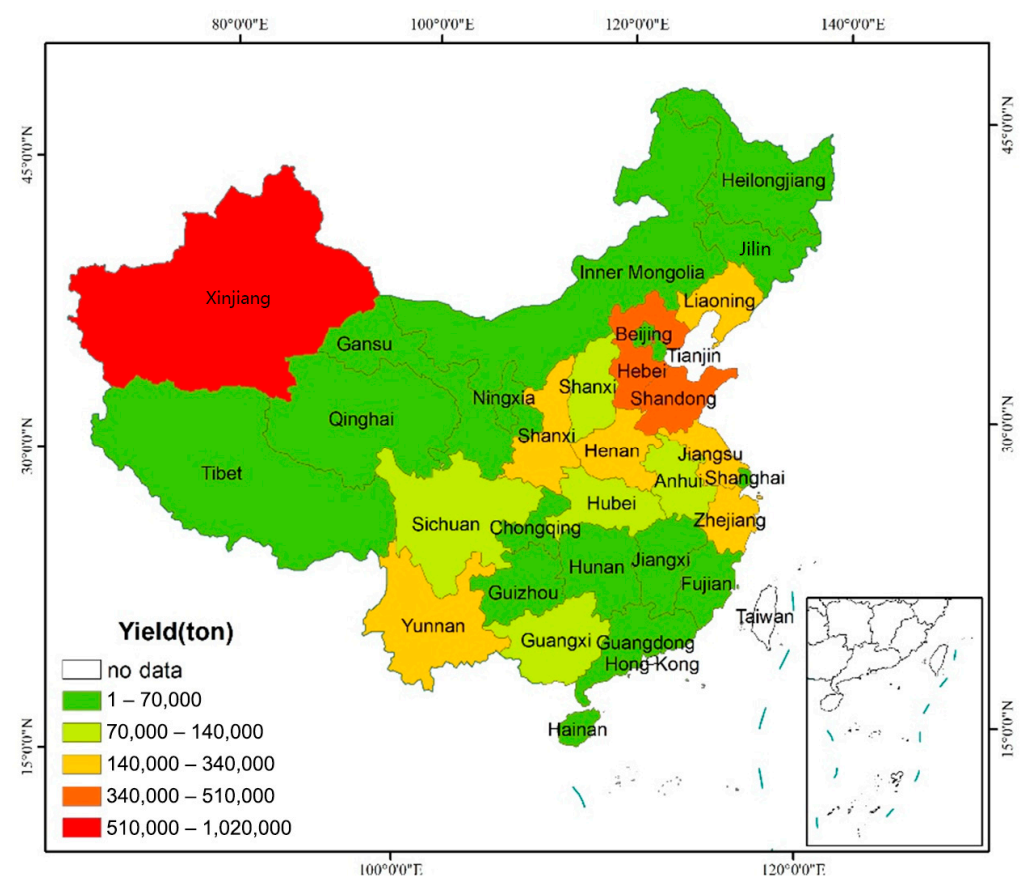

Figure 2. Average annual grape production at the provincial level from 1978 to 2019, China (data from the China Rural Statistical Year Book, 1985-2019, China Statistics). 
At present, grape production is mostly concentrated in the northwest arid region (e.g., Xinjiang, Gansu, Ningxia and Inner Mongolia), the arid and semi-arid area of the Loess Plateau (Shaanxi and Shanxi), the Bohai Bay area (Beijing, Liaoning, Hebei, Tianjin), the ancient riverbed of the Yellow River (Henan, southwestern part of Shandong, North Jiangsu, and North Anhui) and the semi-humid area of the Yunnan-Guizhou Plateau. In these areas, several scholars have published a lot of investigations related to high erosion rates due to wind (e.g., [63]), uncontrolled alluvial processes (e.g., [64]), human impacts (e.g., [65] or inherent vulnerable geological conditions, e.g., [66]. According to data from the China Rural Statistical Year Book (2019), the total vineyard area was $726.2 \times 10^{3}$ ha and the total yield was $14.20 \times 10^{6}$ tons at the end of 2019. The area of vineyards has gradually increased 30 times since 1978 and the yield of the vineyards has increased hundreds of times. In Figure 3, the average annual grape production at the provincial level from 1978 to 2019 in China is mapped showing the enormous importance of the viticulture sector in this country.

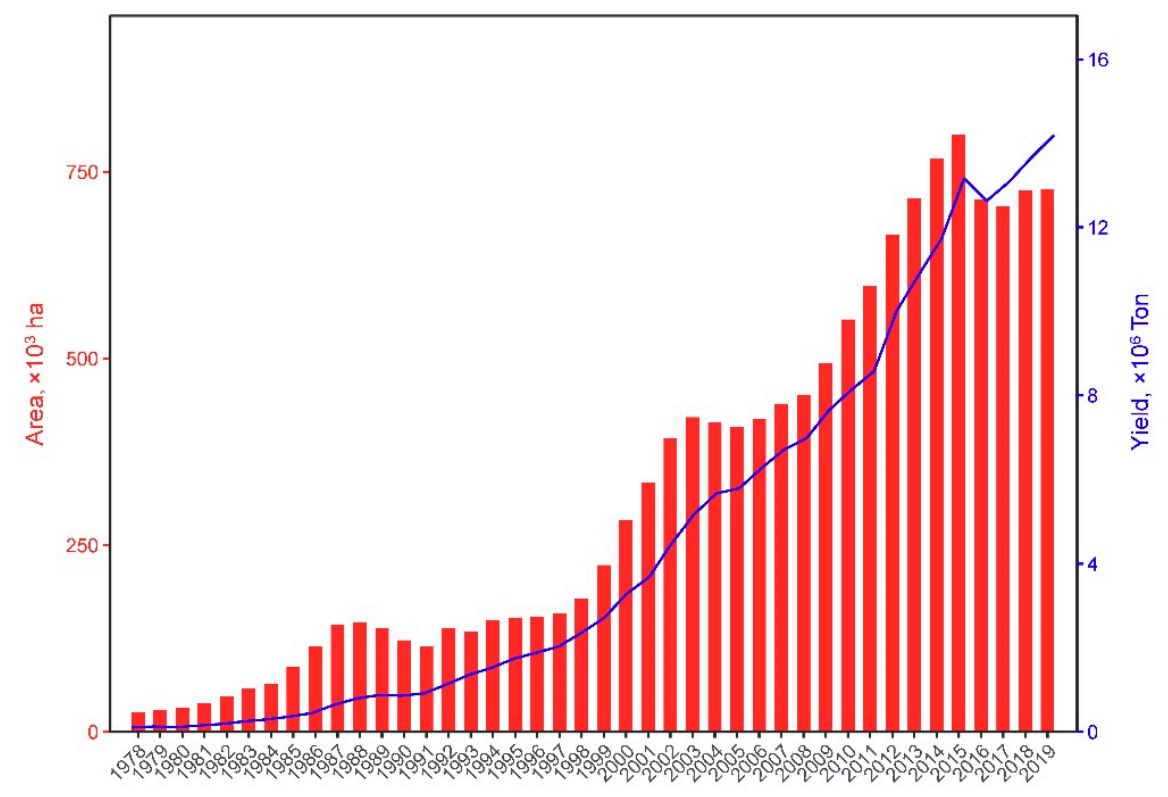

Figure 3. Vineyard area and yield changes from 1978 to 2019 (data from the China Rural Statistical Year Book, 1985-2019, China Statistics).

Arid and semi-arid regions cover a large area of China, mainly in the northwestern region $[67,68]$. In northwest China, water scarcity is a critical issue that restricts local and regional development $[18,69,70]$. Grapes, being the characteristic fruit of the region, have high economic value. However, with limited water resources, the sustainable management of vineyards face many challenges [71]. Land degradation in this region results from various factors, including climate variations and human activities, and results in soil degradation and a severe decrease in potential productivity [72,73]. Measures such as artificial vegetation restoration and grass plantation have worked to control desertification, reduce damage from sandstorms and improve ecological benefits [74,75]. Sustainable development of the regional economy needs promotion of the fruit industry. Therefore, adopting rational operational methods that will not cause degradation under harsh environmental conditions is key to the sustainable development of the vineyard system.

At present, many vineyards have adopted intensive management such as unified irrigation, fertilization, pruning and harvesting based on the traditional farmers' experience $[76,77]$. Chinese farmers take into account the differences in the growth status of grapes at different locations in terms of the need for moisture, fertilizers and pruning in different territories. Furthermore, to maximize water resource and fertilizer utilization efficiency and labor productivity, the use of precision irrigation and harvesting management 
based on yield or quality, namely, precision agriculture, is the inevitable future of modern agriculture in China [72].

The increase in the Chinese vineyard area and production since 2014 is documented in Table 1. It is worth highlighting that China leads the world in grape production, is second in vineyard area (behind Spain) and the fifth among wine importers; however, it is not among the top 15 countries in wine exportation, which demonstrates the local/national character of Chinese vineyards. It is also relevant to remark that China occupies the fifth position related to wine consumption and importation over the world, giving this sector the fourth position in terms of the economic value (2.2 billion EUR).

Table 1. Characterization of Chinese viticulture in the worldwide context. Data obtained from the OIV (International Organization of Vine and Wine) reports published in 2018 and 2019; nd: no data are available for these parameters or Chinese vineyards were not ranked on the top list.

\begin{tabular}{cccccccc}
\hline Variables & $\mathbf{2 0 1 4}$ & $\mathbf{2 0 1 5}$ & $\mathbf{2 0 1 6}$ & $\mathbf{2 0 1 7}$ & $\mathbf{2 0 1 8}$ & $\mathbf{2 0 1 9}$ & $\begin{array}{c}\mathbf{2 0 1 9} \\
\text { Ranking }\end{array}$ \\
\hline Vineyard area (kha) & 813 & 859 & 807 & 830 & 855 & 855 & 2 \\
Grape production (thousand tons) & 12.5 & 13.2 & 12.6 & 13.1 & 11.7 & $\mathrm{Nd}$ & 1 \\
Table grapes (thousand tons) & 9.4 & 10.0 & 10.1 & 10.5 & 9.5 & $\mathrm{Nd}$ & 1 \\
Dried grapes (thousand tons) & 180 & 190 & 165 & 180 & 190 & $\mathrm{Nd}$ & 3 \\
Wine production (million hl) & 13.5 & 13.3 & 13.2 & 11.6 & 9.1 & $\mathrm{Nd}$ & 10 \\
Wine consumption (million hl) & 17.4 & 18.1 & 19.2 & 19.3 & 17.6 & 17.8 & 5 \\
Wine importation (million hl) & 3.8 & 5.6 & 6.4 & 7.5 & 6.9 & 6.1 & 5 \\
Value (billion EUR) & nd & nd & nd & nd & 2.4 & 2.2 & 4 \\
\hline
\end{tabular}

\section{Soil Degradation in Vineyards: An Opportunity for Research in China?}

\subsection{Hypothesis about Soil Erosion and Factors in Chinese Vineyards}

Soil erosion rates in vineyards can be even higher in comparison to other types of orchards such as olive, almond, apricot, citrus, avocado, as well as cereal crop plantations [19]. Studies of soil erosion in vineyards have primarily focused on three specific countries: France, Italy and Spain, which are known as "Mediterranean vineyards" in the scientific literature. The International Organization of Vine and Wine (OIV) estimated the total worldwide surface area for vineyards at about 7.4 Mha in 2018, of which Spain, France and Italy comprise $13 \%, 11 \%$ and $9 \%$, respectively. These same three countries also represented the highest wine production ( $50 \%$ combined) and wine exportation in terms of volume and monetary value. However, several other countries also have large areas of vineyards, such as China, which has the highest total grape production, reaching 11.7 million tons annually. This shows that grape production is not just a Mediterranean specialty, although the perception of much of the population is that wine is synonymous with Mediterranean areas. China's vineyards are expanding and production is expected to increase by 900,000 tons in the five coming years, although these estimates may be affected by the COVID-19 crisis [78,79]. As a country with a developing wine industry, China has attracted the interest of both domestic and foreign investors.

Vineyards are usually found on steep slopes as they are located on less productive soils [80]. Some of these slopes reach more than $50 \%$ such as in the Saar and Mosel valleys in Germany, Douro valley, Portugal [81], or Montes de Málaga in Southern Spain [82]. Vine plantations typically occupy fragile soils characterized by extremely basic or acidic $\mathrm{pH}$, clay or loamy textures, low soil water retention capacity and total organic carbon values lower than $3 \%$; these soils are often formed in marls or limestones $[16,83,84]$. The fragile soils often found in vineyards can contribute to high soil loss rates and overland flow discharge even when they have negligible slope angles, which is true, for example, for the vineyards of the Loess Plateau. Rock fragment cover has been identified as a key factor influencing erosion in vineyard soils [85]. Rock fragments are often embedded in the soil and act as a crust or armor that minimizes sediment detachment and reduces soil losses and the splash effect $[86,87]$. Several authors have indicated the possibility that climate change could 
increase soil erosion rates and productivity losses in vineyards as well as the transport of pollutants [88,89]. Finally, vegetation cover, animals and microorganisms act as important environmental factors controlling soil quality $[90,91]$. Sporadic natural vegetation cover can hold soil in place against sediment transport and overland flow episodes through the roots and by protecting the soil surface as they intercept raindrops and reduce the splash effect in the inter-row areas [92]. However, vegetation is commonly removed from vineyards due to water scarcity and the negative view of vegetated fields held by farmers [93]. Therefore, more research should focus on assessing the most effective strategies to conserve an equilibrium between biodiversity and vineyard soil conservation. The most important anthropogenic factor that enhances soil erosion as reported by almost all scientific literature related to vineyards is the practice of keeping soils bare [94-96]. In China, although the use of greenhouses to grow grapes has been applied in various regions, conventional farming is still the most typical soil management system, characterized by the application of herbicides and the use of machinery and hand tillage to eliminate weeds. This land use management likely enhances local soil erosion, but also creates problems at the catchment scale such as landslides, floods and pollutant transport. In China, like in other viticultural regions, one important issue that has largely been overlooked in terms of soil erosion is the age of the plantations. This is because large amounts of sediments could be mobilized and the soil structure would be changed dramatically when the surface of the hillslope is levelled [97]. Therefore, during the first and second year after planting the vines, the soil is not well-consolidated or protected by the young plants, and the impact of raindrops is larger by up to an order of magnitude than after 5, 10 and 25 years after plantation took place [98]. Future research into this issue should not only address the biophysical approach, but also social and economic constraints farmers face when they apply new management strategies and how to increase efficiency. Within these issues, the perception of farmers and possible subsidies to support the management strategies that are promoted will be essential to finally achieve sustainable agriculture, which is characterized by conservation of biodiversity, soil fertility, clean production and high-quality products [99-101].

A very important focus of future research needs to consist in finding suitable solutions based on inexpensive and accessible materials and management practices that are useful and do not generate a bad perception among the wine- and vine-growers who implement these strategies in China. These solutions should allow the development of suitable land management plans that can easily be transmitted to Chinese stakeholders and policymakers. Solutions should be sought that follow the concept of nature-based solutions [102,103]. Management strategies based on this idea are in principle more sustainable as they are designed to improve themselves over time and create less connectivity of water and sediment, which is beneficial to farms because they conserve and improve soil and water availability [104]. All of the abovementioned reasons make the soil erosion research idea vital to fill these gaps in our current information base, which would help to solve a potential future irreparable environmental issue: the loss of fertile soil in Chinese vineyards.

Table 2 summarizes the publications found on soil erosion in vineyards for China. It is important to note that only specific papers dealing with the main topic with vineyards are summarized. Logically, global or Chinese maps or surveys of soil erosion that very probably included vineyards were not considered here. This is relevant to be noted to avoid concluding that there are no studies on those systems specifically as the main topic. We used the most important literature databases (Google Scholar and Web of Knowledge) and some article finders from specific publishing houses (Elsevier/Science Direct, Wiley, Springer, Taylor and Francis, SAGE, MDPI and Frontiers) that have numerous specialized journals on environmental, agricultural and social sciences. We introduced the same keywords in all the searches: "soil erosion", "vineyard" and "China". 
Table 2. Literature overview related to soil erosion in Chinese vineyards.

\begin{tabular}{cccc}
\hline Database/Finder & $\begin{array}{c}\text { Assessed Results } \\
\text { (27 January 2021) }\end{array}$ & Results & $\begin{array}{c}\text { Articles about } \\
\text { Vineyards }\end{array}$ \\
\hline Google Scholar & Most relevant (first 50 pages) & 16,300 (records) & 0 \\
Web of Knowledge & Total articles & 8 (articles) & 0 \\
Science Direct & Total articles & 689 (articles) & 0 \\
Wiley Online Library & Total articles & 345 articles & 0 \\
Springer Link & Total articles & 205 articles & 0 \\
Taylor and Francis & Total articles & 265 articles & 0 \\
MDPI & Total articles & 0 articles & 0 \\
Frontiers & Total articles & 4543 articles & 0 \\
\hline
\end{tabular}

\subsection{Key Topics and Possible Research Lines to Elaborate a Research Plan to Assess Soil Erosion} in China

A flowchart with different steps or possible working packages that could be included within a research program to evaluate soil erosion in Chinese vineyards is presented in Figure 4.

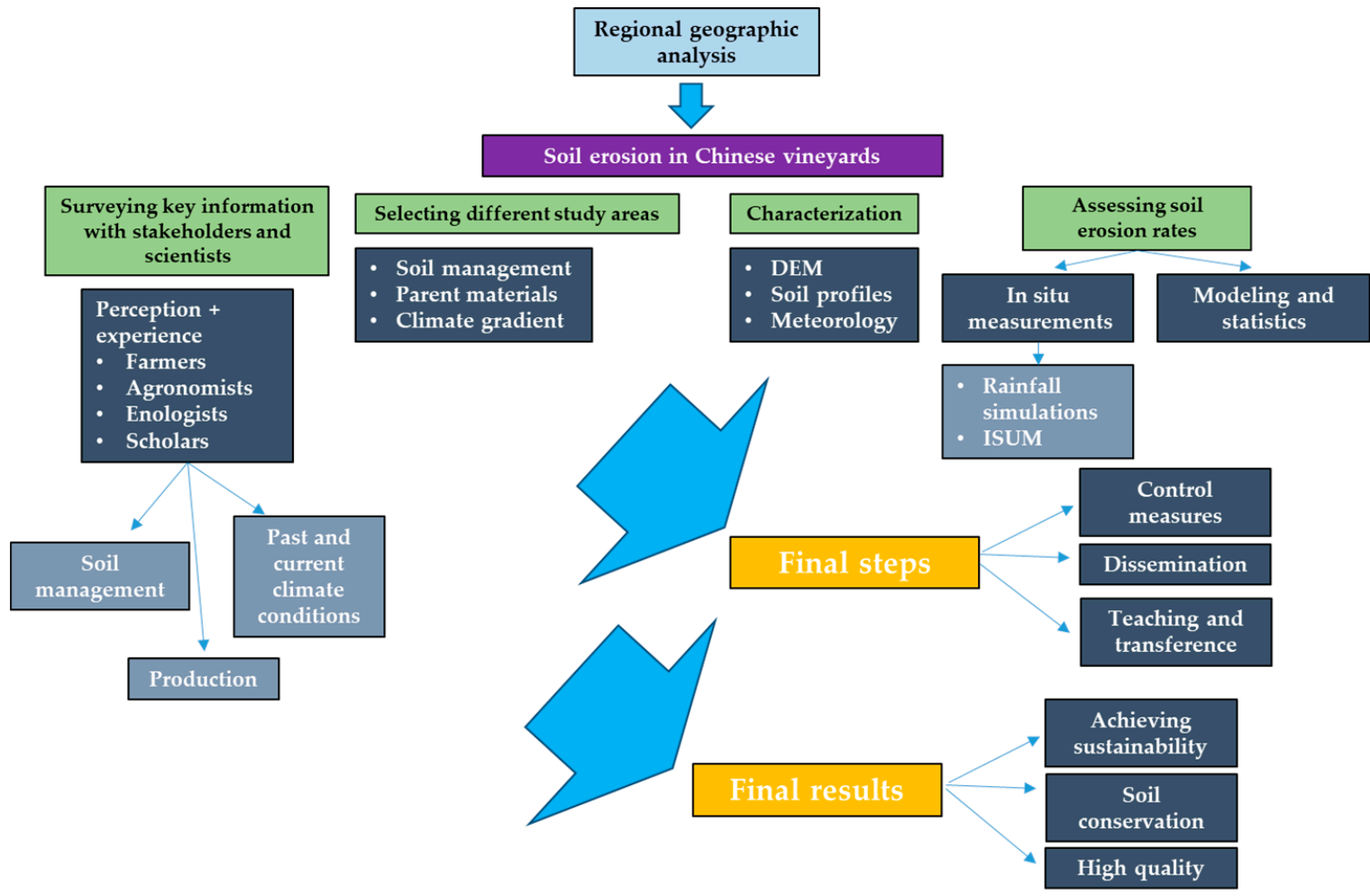

Figure 4. A flowchart showing the potential steps or working packages to design a research plan to investigate soil erosion in Chinese vineyards. DEM: Digital Elevation Model; ISUM: Improved Stock Unearthing Method.

\subsubsection{Surveying Key Information with Stakeholders and Scientists}

As long as no previous scientific literature on soil erosion in vineyards as the main topic was found for China, round tables should be organized with stakeholders and scientists, especially agronomists and enologists, to survey the main general ideas about soil dynamics, climate and production based on their perceptions. After this, the next step would be related to the selection of specific study areas located in viticultural regions (e.g., Figure 5), which are representative of the main agronomic and environmental factors found in these regions such as climate, parent materials, slope ranges, soil management and grape varieties. 

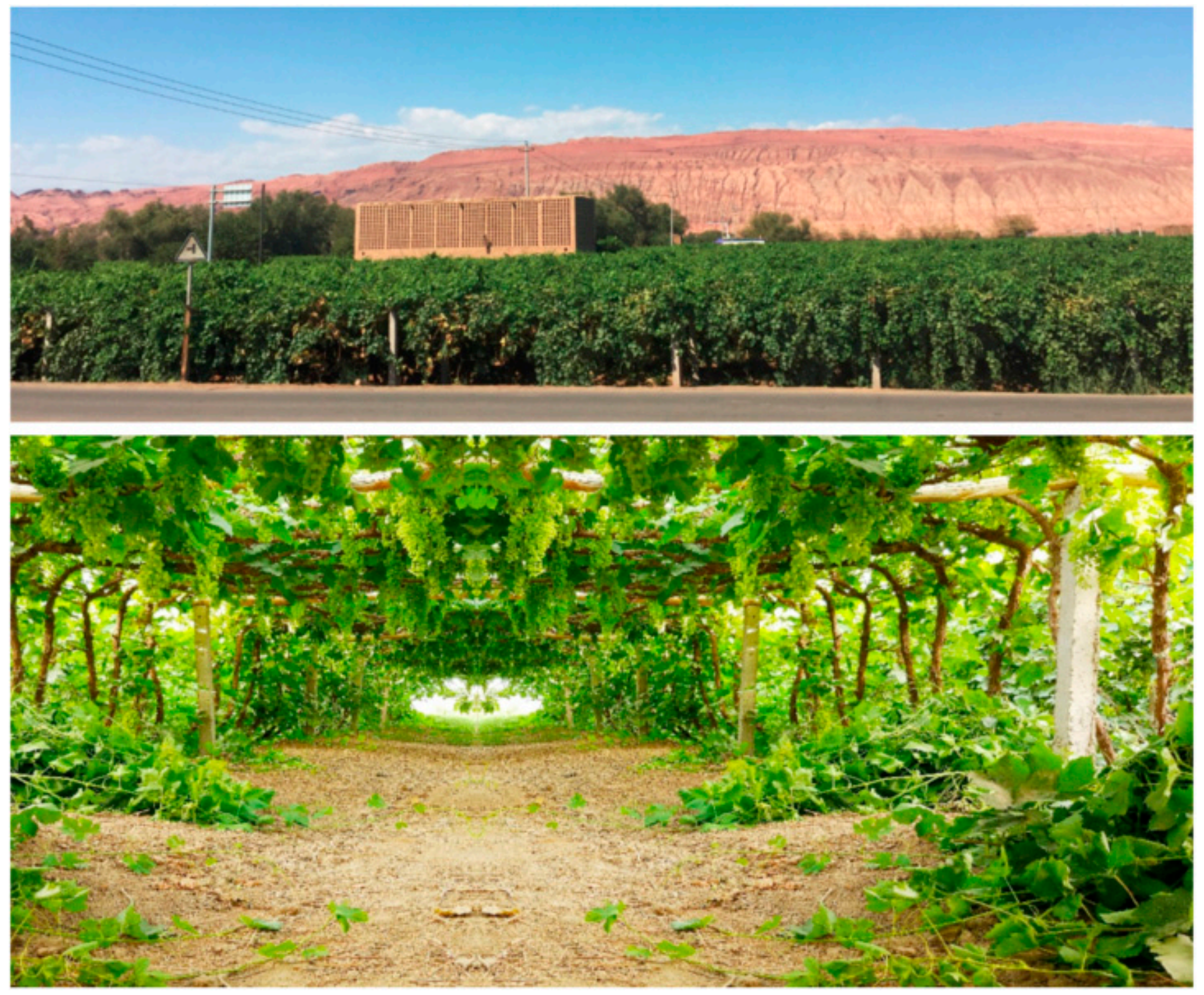

Figure 5. Examples of study areas in Chinese vineyards. Above: the Flaming Mountains, Turpan, Xinjiang Uyghur Autonomous Region. Below: vineyards of the Lukeqin Town, Shanshan Country, Turpan, Xinjiang Uyghur Autonomous Region. Photographs provided by Dr Abdulla Abliz from Xinjiang University, Dr Osmanjan Ilniyaz from Wuhan University. Special thanks to Dr Maierdang Keyimu from the Research Center for Eco-Environmental Sciences, Chinese Academy of Sciences.

\subsubsection{Background Characterization of Each Study Area}

After selecting the main study areas, it is necessary to evaluate where soil erosion is occurring and how much soil is being lost. It could be helpful to make a previous selection of which topographic variables can be extracted from a digital elevation model (DEM) considering the major covariates that in combination affect soil erosion such as aspect, topographic humidity index, upper ridge flatness index, multiple resolution valley bottom flatness index, curvature, profile, orientation and slope. Furthermore, determination of which climatic variables should be considered given the availability of data about changes in the pluviometry and temperature patterns from statistical analysis of the incidence, intensity, extension and frequency of rainfall should be conducted. If there are no meteorological stations close to the study areas, it will be necessary to at least install rain gauges at each plot. Moreover, soil samples should be taken and soil profiles should be described. We recommend sampling specific points (above and below the hillslope, under plants 
and between the inter-rows, with at least three replicates), which should be distributed according to representative criteria [105]. Some key properties to be analyzed are soil texture, stoniness, organic matter, $\mathrm{pH}$, cation exchange capacity, electrical conductivity and water retention capacity.

\subsubsection{Assessing In Situ Soil Erosion Rates Using Field Measurements}

The improved stock unearthing method (ISUM) [106,107] and rainfall simulation experiments $[108,109]$ can be performed to determine the first in situ soil erosion results and give enough information to discuss methods, future research lines and challenges. Rainfall simulation experiments can be conducted with a portable simulator (15-20 repetitions) following standard methodology [110] to obtain the starting data for the erosive processes related to the activation of runoff, soil loss and sediment concentration. It is recommended that these measurements be made on bare soils and soils with vegetation cover to test the differences.

\subsubsection{Applying Modeling and Statistical Analysis to Model Soil Erosion at a Larger Scale}

Analyzing and comparing which factors enhance soil and water loss in viticultural regions at a larger scale is key. Determining which statistical analysis scheme must be adopted to make the results comparable and meaningful is necessary. Advanced statistical models such as network analysis, redundancy analysis and structural equation model will be considered for detecting the relationship between all of the abiotic (e.g., rainfall and topographic factors) and biotic (e.g., soil indicators) factors, and then the contribution of each of them will be estimated [91,111-113].

\subsubsection{Evaluation of Local Farmers' Perception and Press Awareness}

Designing and utilizing a survey that investigates stakeholder perceptions about soil erosion in vineyards in China and other countries will be important. Farmers and other stakeholders can provide information about local needs, worries, awareness and environmental perception of the vineyards to determine the willingness of local communities to adopt different management strategies. From the scientific point of view, knowing this will allow us to determine if soil erosion is considered a real problem and how it can be solved. Finally, the press and social media should also be checked to collect the information that appears in the headlines and stories of the most prominent provincial newspapers, websites and social media (influencers, enologists, websites, etc.). This will also give overview information regarding extreme climatic phenomenology and its incidence in rural areas in general and in wine areas in particular.

\subsubsection{Designing Solutions to Reduce Soil Loss and Achieve Sustainable Crop Management}

Finally, it is necessary to propose specific plans to reduce or stop soil erosion, with solutions like catch crops, straw mulch, vegetation cover, no-till farming, etc. being among many potential options. After integrating the experimental and survey results, it will be possible to propose some alternatives in the form of one report (in English and Chinese). Reports should be validated by a panel of experts via questionnaires sent to the most cited experts on soil erosion in vineyards around the world. Finally, the reports should be formally introduced to the local Chinese authorities.

\section{Conclusions}

To date, we have not found studies published in indexed journals related to soil erosion in Chinese vineyards as the main topic like the ones published on vineyards in European, American or Oceanic countries. This situation gives scholars an opportunity to initiate a new research line. Considering previous works in vineyards and land degradation, it would be logical to suppose that the results will help farmers, stakeholders and policymakers to face an irreparable environmental issue. Considering prospects, a clear and feasible structure to assess soil erosion in vineyards would be related to the following 
steps: (i) assessing where and how much soil erosion affects Chinese viticultural regions; (ii) discovering which factors drive soil and water loss; (iii) evaluating local farmers' perceptions as well as press and social media awareness; (iv) planning which solutions should be utilized to reduce soil loss and achieve sustainable crop management and (v) producing scientific dissemination of the results at the national and international level.

Author Contributions: Conceptualization, J.R.-C. and Y.Y.; methodology, J.R.-C. and Y.Y.; formal analysis, J.R.-C. and Y.Y.; investigation, J.R.-C. and Y.Y.; writing — original draft preparation, J.R.-C. and Y.Y.; writing-review and editing, J.R.-C. and Y.Y.; visualization, J.R.-C. and Y.Y. All authors have read and agreed to the published version of the manuscript.

Funding: Yang Yu received the Young Elite Scientist Sponsorship Program from the China Association for Science and Technology (2017-2019).

Acknowledgments: Special thanks to colleagues that provided useful and constructive ideas such as Artemi Cerdà and Eric C. Brevik. Furthermore, we thank Abo Li from Ningxia Academy of Agricultural and Forestry Sciences, Abdulla Abliz from Xinjiang University, Osmanjan Ilniyaz from Wuhan University, Maierdang Keyimu from the Research Center for Eco-Environmental Sciences, Chinese Academy of Sciences, for providing photographs. We would also like to thank Weixin Zhang, Hengshuo Zhang and Rao Liu for their assistance in investigating the distribution of vineyards in China. Jesús Rodrigo-Comino wants to especially thank his wife Ana and two children, Martín and Alicia, for their patience in respect of work on this article in these difficult times. Finally, we want to thank reviewers, the managing editor and guest editors for their time and efforts to help us to improve this research.

Conflicts of Interest: The authors declare no conflict of interest.

\section{References}

1. Mhazo, N.; Chivenge, P.; Chaplot, V. Tillage impact on soil erosion by water: Discrepancies due to climate and soil characteristics. Agric. Ecosyst. Environ. 2016, 230, 231-241. [CrossRef]

2. Amate, J.I.; De Molina, M.G.; Vanwalleghem, T.; Fernández, D.S.; Gómez, J.A. Erosion in the Mediterranean: The Case of Olive Groves in the South of Spain (1752-2000). Environ. Hist. 2013, 18, 360-382. [CrossRef]

3. Mamedov, A.I.; Levy, G.J. Soil erosion-runoff relations on cultivated land: Insights from laboratory studies. Eur. J. Soil Sci. 2018, 70, 686-696. [CrossRef]

4. Jarašiūnas, G.; Świtoniak, M.; Kinderienè, I. Dynamics of slope processes under changing land use conditions in young morainic landscapes, Western Lithuania. Int. Agrophys. 2020, 1, 43-55. [CrossRef]

5. Heidari, A.; Kumar, V.; Keshavarzi, A. Appraisal of metallic pollution and ecological risks in agricultural soils of Alborz province, Iran, employing contamination indices and multivariate statistical analyses. Int. J. Environ. Health Res. 2019, 1-19. [CrossRef]

6. Sigua, G.C.; Palhares, J.C.P.; Kich, J.D.; Mulinari, M.R.; Mattei, R.M.; Klein, J.B.; Muller, S.; Plieske, G. Microbiological Quality Assessment of Watershed Associated with Animal-Based Agriculture in Santa Catarina, Brazil. Water Air Soil Pollut. 2010, 210, 307-316. [CrossRef]

7. Ebong, G.A.; Ettesam, E.S.; Dan, E.U. Impact of Abattoir Wastes on Trace Metal Accumulation, Speciation, and Human HealthRelated Problems in Soils within Southern Nigeria. Air Soil Water Res. 2020, 13. [CrossRef]

8. Bagherzadeh, A.; Gholizadeh, A.; Keshavarzi, A. Assessment of soil fertility index for potato production using integrated Fuzzy and AHP approaches, Northeast of Iran. Eurasian J. Soil Sci. 2018, 7, 203-212. [CrossRef]

9. Choi, J.-S.; Kim, M.-T.; Ryu, J.-H.; Kim, K.S.; Kim, S.-J.; Park, K.-D. Effect of Legume Cover Crops and Nitrogen Fertilization Rates on Yield and Nitrogen Use Efficiency of Waxy Corn (Zea mays L.) in No-Tillage System. Korean J. Soil Sci. Fertil. 2016, 49, 531-540. [CrossRef]

10. Novara, A.; Pisciotta, A.; Minacapilli, M.; Maltese, A.; Capodici, F.; Cerdà, A.; Gristina, L. The impact of soil erosion on soil fertility and vine vigor. A multidisciplinary approach based on field, laboratory and remote sensing approaches. Sci. Total Environ. 2018, 474-480. [CrossRef]

11. Hietala-Koivu, R.; Lankoski, J.; Tarmi, S. Loss of biodiversity and its social cost in an agricultural landscape. Agric. Ecosyst. Environ. 2004, 103, 75-83. [CrossRef]

12. Eppink, F.V.; Bergh, J.C.V.D.; Rietveld, P. Modelling biodiversity and land use: Urban growth, agriculture and nature in a wetland area. Ecol. Econ. 2004, 51, 201-216. [CrossRef]

13. Assandri, G.; Bogliani, G.; Pedrini, P.; Brambilla, M. Assessing common birds' ecological requirements to address nature conservation in permanent crops: Lessons from Italian vineyards. J. Environ. Manag. 2017, 191, 145-154. [CrossRef] [PubMed]

14. Prosdocimi, M.; Cerdà, A.; Tarolli, P. Soil water erosion on Mediterranean vineyards: A review. Catena 2016, 141, 1-21. [CrossRef] 
15. Vaudour, E.; Leclercq, L.; Gilliot, J.; Chaignon, B. Retrospective 70 y-spatial analysis of repeated vine mortality patterns using ancient aerial time series, Pléiades images and multi-source spatial and field data. Int. J. Appl. Earth Obs. Geoinf. 2017, 58, 234-248. [CrossRef]

16. Blavet, D.; De Noni, G.; Le Bissonnais, Y.; Leonard, M.; Maillo, L.; Laurent, J.; Asseline, J.; Leprun, J.; Arshad, M.; Roose, E. Effect of land use and management on the early stages of soil water erosion in French Mediterranean vineyards. Soil Tillage Res. 2009, 106, 124-136. [CrossRef]

17. OIV (International Organisation of Vine and Wine Intergovernmental Organisation). 2018 Statistical Report on World Vitivinicult; International Organisation of Vine and Wine Intergovernmental Organisation: Paris, France, 2019; p. 23. Available online: https:/ / www.oiv.int/en/technical-standards-and-documents/statistical-analysis/state-of-vitiviniculture (accessed on 19 February 2021).

18. Wang, X.; Xie, X.; Chen, N.; Wang, H.; Li, H. Study on Current Status and Climatic Characteristics of Wine Regions in China. VITIS J. Grapevine Res. 2018, 57, 9-16. [CrossRef]

19. Rodrigo-Comino, J. Five decades of soil erosion research in "terroir". The State-of-the-Art. Earth Sci. Rev. 2018, 179, 436-447. [CrossRef]

20. Akhtar-Schuster, M.; Stringer, L.C.; Erlewein, A.; Metternicht, G.; Minelli, S.; Safriel, U.; Sommer, S. Unpacking the concept of land degradation neutrality and addressing its operation through the Rio Conventions. J. Environ. Manag. 2017, 195, 4-15. [CrossRef]

21. Cowie, A.L.; Orr, B.J.; Sanchez, V.M.C.; Chasek, P.; Crossman, N.D.; Erlewein, A.; Louwagie, G.; Maron, M.; Metternicht, G.I.; Minelli, S.; et al. Land in balance: The scientific conceptual framework for Land Degradation Neutrality. Environ. Sci. Policy 2018, 79, 25-35. [CrossRef]

22. Visser, S.; Keesstra, S.; Maas, G.; De Cleen, M.; Molenaar, C. Soil as a Basis to Create Enabling Conditions for Transitions Towards Sustainable Land Management as a Key to Achieve the SDGs by 2030. Sustainability 2019, 11, 6792. [CrossRef]

23. Zhang, J.; Wang, E.T.; Singh, R.P.; Guo, C.; Shang, Y.; Chen, J.; Liu, C. Grape berry surface bacterial microbiome: Impact from the varieties and clones in the same vineyard from central China. J. Appl. Microbiol. 2018, 126, 204-214. [CrossRef] [PubMed]

24. Sun, X.; Ma, T.; Xiangyu, S.; Huang, W.; Fang, Y.; Zhan, J. Investigation of the copper contents in vineyard soil, grape must and wine and the relationship among them in the Huaizhuo Basin Region, China: A preliminary study. Food Chem. 2018, 241, 40-50 [CrossRef]

25. Griggs, D.; Stafford-Smith, M.; Gaffney, O.; Rockström, J.; Öhman, M.C.; Shyamsundar, P.; Steffen, W.; Glaser, G.; Kanie, N.; Noble, I. Policy: Sustainable Development Goals for People and Planet. Nature 2013, 495, 305. [CrossRef] [PubMed]

26. Keesstra, S.; Mol, G.; De Leeuw, J.; Okx, J.; Molenaar, C.; De Cleen, M.; Visser, S. Soil-Related Sustainable Development Goals: Four Concepts to Make Land Degradation Neutrality and Restoration Work. Land 2018, 7, 133. [CrossRef]

27. Richter, G. Der Aufbau der Forschungsstelle Bodenerosion und die Ersten Messungen in Weinbergslagen; Forschungsstelle Bodenerosion, University Trier: Trier, Germany, 1975.

28. Richter, G. Bodenerosion in Rebanlagen des Moselgebietes. Ergebnisse Quantitativer Untersuchungen 1974-1977; Forschungsstelle Bodenerosion, University Trier: Trier, Germany, 1979.

29. Merino, R.; Etchevers Barra, J.; Peña, L.; Navea, O. Efectos de Sistemas de Manejo de Suelo Sobre La Erosión y Producción En Viñedos de Secano. Chil. J. Agric. Res. 1979, 39, 35-40.

30. Ramos, M.; Porta, J. Analysis of design criteria for vineyard terraces in the mediterranean area of North East Spain. Soil Technol. 1997, 10, 155-166. [CrossRef]

31. Ruiz-Colmenero, M.; Bienes, R.; Marques, M. Soil and water conservation dilemmas associated with the use of green cover in steep vineyards. Soil Tillage Res. 2011, 117, 211-223. [CrossRef]

32. Biddoccu, M.; Ferraris, S.; Pitacco, A.; Cavallo, E. Temporal variability of soil management effects on soil hydrological properties, runoff and erosion at the field scale in a hillslope vineyard, North-West Italy. Soil Tillage Res. 2017, 165, 46-58. [CrossRef]

33. Novara, A.; Gristina, L.; Saladino, S.; Santoro, A.; Cerdà, A. Soil erosion assessment on tillage and alternative soil managements in a Sicilian vineyard. Soil Tillage Res. 2011, 117, 140-147. [CrossRef]

34. Pappalardo, S.E.; Gislimberti, L.; Ferrarese, F.; De Marchi, M.; Mozzi, P. Estimation of potential soil erosion in the Prosecco DOCG area (NE Italy), toward a soil footprint of bottled sparkling wine production in different land-management scenarios. PLoS ONE 2019, 14, e0210922. [CrossRef] [PubMed]

35. Quiquerez, A.; Brenot, J.; Garcia, J.-P.; Petit, C. Soil degradation caused by a high-intensity rainfall event: Implications for medium-term soil sustainability in Burgundian vineyards. Catena 2008, 73, 89-97. [CrossRef]

36. Paroissien, J.-B.; Lagacherie, P.; Le Bissonnais, Y. A regional-scale study of multi-decennial erosion of vineyard fields using vine-stock unearthing-burying measurements. Catena 2010, 82, 159-168. [CrossRef]

37. Novák, T.J.; Incze, J.; McLeod, A.; Giani, L. Development of Soil Organic Carbon Pools after Vineyard Abandonment. Soil Sci. Ann. 2020, 71, 236-245. [CrossRef]

38. Novák, T.J.; Incze, J.; Spohn, M.; Glina, B.; Giani, L. Soil and vegetation transformation in abandoned vineyards of the Tokaj Nagy-Hill, Hungary. Catena 2014, 123, 88-98. [CrossRef]

39. Bogunović, I.; Kisić, I.; Jurisić, A. Soil Compaction under Different Tillage System on Stagnic Luvisols. Agric. Conspec. Sci. 2014, $79,57-63$.

40. Okur, N.; Kayikcioglu, H.; Ates, F.; Yagmur, B. A comparison of soil quality and yield parameters under organic and conventional vineyard systems in Mediterranean conditions (West Turkey). Biol. Agric. Hortic. 2015, 32, 73-84. [CrossRef] 
41. Cao, S.; Liu, Y.; Yu, Z. China's Successes at Combating Desertification Provide Roadmap for Other Nations. Environ. Sci. Policy Sustain. Dev. 2018, 60, 16-24. [CrossRef]

42. Li, T.; Wang, Y.; Zhao, D. Environmental Kuznets Curve in China: New evidence from dynamic panel analysis. Energy Policy 2016, 91, 138-147. [CrossRef]

43. Wan, J.; Su, Y.; Zan, H.; Zhao, Y.; Zhang, L.; Zhang, S.; Dong, X.; Deng, W. Land Functions, Rural Space Governance, and Farmers' Environmental Perceptions: A Case Study from the Huanjiang Karst Mountain Area, China. Land 2020, 9, 134. [CrossRef]

44. Bryan, B.A.; Gao, L.; Ye, Y.; Sun, X.; Connor, J.D.; Crossman, N.D.; Stafford-Smith, M.; Wu, J.; He, C.; Yu, D.; et al. China's response to a national land-system sustainability emergency. Nat. Cell Biol. 2018, 559, 193-204. [CrossRef] [PubMed]

45. Zhang, Y.; Kang, S.; Ward, E.J.; Ding, R.; Zhang, X.; Zheng, R. Evapotranspiration components determined by sap flow and microlysimetry techniques of a vineyard in northwest China: Dynamics and influential factors. Agric. Water Manag. 2011, 98, 1207-1214. [CrossRef]

46. Wang, S.; Zhu, G.; Xia, D.; Ma, J.; Han, T.; Ma, T.; Zhang, K.; Shang, S. The characteristics of evapotranspiration and crop coefficients of an irrigated vineyard in arid Northwest China. Agric. Water Manag. 2019, 212, 388-398. [CrossRef]

47. Zhao, P.; Li, S.; Li, F.; Du, T.; Tong, L.; Kang, S. Comparison of dual crop coefficient method and Shuttleworth-Wallace model in evapotranspiration partitioning in a vineyard of northwest China. Agric. Water Manag. 2015, 160, 41-56. [CrossRef]

48. Wu, L.; Pan, X.; Chen, L.; Huang, Y.; Teng, Y.; Luo, Y.; Christie, P. Occurrence and distribution of heavy metals and tetracyclines in agricultural soils after typical land use change in east China. Environ. Sci. Pollut. Res. 2013, 20, 8342-8354. [CrossRef] [PubMed]

49. Liang, H.; Wang, X.; Yan, J.; Luo, L. Characterizing the Intra-Vineyard Variation of Soil Bacterial and Fungal Communities. Front. Microbiol. 2019, 10, 1239. [CrossRef]

50. Novara, A.; Gristina, L.; Guaitoli, F.; Santoro, A.; Cerdà, A. Managing soil nitrate with cover crops and buffer strips in Sicilian vineyards. Solid Earth 2013, 4, 255-262. [CrossRef]

51. Bao, Y.; Cheng, L.; Bao, Y.; Yang, L.; Jiang, L.; Long, C.; Kong, Z.; Peng, P.; Xiao, J.; Lu, Q. Desertification: China provides a solution toa global challenge. Front. Agric. Sci. Eng. 2017, 4, 402-413. [CrossRef]

52. Wei, W.; Gao, Y.; Huang, J.; Gao, J. Exploring the effect of basin land degradation on lake and reservoir water quality in China. J. Clean. Prod. 2020, 268, 122249. [CrossRef]

53. Zhang, K.; Yu, Z.; Li, X.; Zhou, W.; Zhang, D. Land use change and land degradation in China from 1991 to 2001. Land Degrad. Dev. 2006, 18, 209-219. [CrossRef]

54. Chen, L.; Wei, W.; Fu, B.; Lü, Y. Soil and water conservation on the Loess Plateau in China: Review and perspective. Prog. Phys. Geogr. Earth Environ. 2007, 31, 389-403. [CrossRef]

55. Yu, Y.; Zhao, W.; Martinez-Murillo, J.F.; Pereira, P. Loess Plateau: From degradation to restoration. Sci. Total. Environ. 2020, 738, 140206. [CrossRef] [PubMed]

56. Gu, C.; Mu, X.; Gao, P.; Zhao, G.; Sun, W.; Tan, X. Distinguishing the effects of vegetation restoration on runoff and sediment generation on simulated rainfall on the hillslopes of the loess plateau of China. Plant Soil 2019, 447, 393-412. [CrossRef]

57. Wang, H.; Zhang, G.-H.; Li, N.-N.; Zhang, B.-J.; Yang, H.-Y. Soil erodibility as impacted by vegetation restoration strategies on the Loess Plateau of China. Earth Surf. Process. Landf. 2019, 44, 796-807. [CrossRef]

58. Zhang, B.; He, C.; Burnham, M.; Zhang, L. Evaluating the coupling effects of climate aridity and vegetation restoration on soil erosion over the Loess Plateau in China. Sci. Total. Environ. 2016, 539, 436-449. [CrossRef] [PubMed]

59. Jiang, H.-E.; Zhang, Y.-B.; Li, X.; Yao, Y.-F.; Ferguson, D.K.; Lü, E.-G.; Li, C.-S. Evidence for early viticulture in China: Proof of a grapevine (Vitis vinifera L., Vitaceae) in the Yanghai Tombs, Xinjiang. J. Archaeol. Sci. 2009, 36, 1458-1465. [CrossRef]

60. Liu, X. Viticulture and Viniculture in the Turfan Region. Silk Road 2005, 3, 23-27.

61. Shou Bo, H.; Zhi Yin, C.; Chao Dong, S.; McIntyre, G.N.; Bridgman, H.A. A Study on Climatic Subdivisions for the Viticulture in China. J. Zhejiang Univ. Agric. Life Sci. 2000, 26, 670-674.

62. Aleixandre, J.L.; Aleixandre-Tudó, J.L.; Bolaños-Pizarro, M.; Aleixandre-Benavent, R. Global trends in scientific production in enology and viticulture in selected emerging economies (BRIC). Scientometrics 2015, 103, 649-668. [CrossRef]

63. Li, D.; Xu, E.; Zhang, H. Influence of ecological land change on wind erosion prevention service in arid area of northwest China from 1990 to 2015. Ecol. Indic. 2020, 117, 106686. [CrossRef]

64. Pan, B.; Gao, H.; Wu, G.; Li, J.; Li, B.; Ye, Y. Dating of erosion surface and terraces in the eastern Qilian Shan, northwest China. Earth Surf. Process. Landf. 2006, 32, 143-154. [CrossRef]

65. Zhang, W.; Xing, S.; Hou, X. Evaluation of soil erosion and ecological rehabilitation in Loess Plateau region in Northwest China using plutonium isotopes. Soil Tillage Res. 2019, 191, 162-170. [CrossRef]

66. Feng, T.; Chen, H.; Polyakov, V.O.; Wang, K.; Zhang, X.; Zhang, W. Soil erosion rates in two karst peak-cluster depression basins of northwest Guangxi, China: Comparison of the RUSLE model with 137Cs measurements. Geomorphology 2016, 253, 217-224. [CrossRef]

67. Liu, X.; Zhang, D.; Luo, Y.; Liu, C. Spatial and temporal changes in aridity index in northwest China: 1960 to 2010. Theor. Appl. Clim. 2012, 112, 307-316. [CrossRef]

68. Qian, C.; Zhou, T. Multidecadal Variability of North China Aridity and Its Relationship to PDO during 1900-2010. J. Clim. 2014, 27, 1210-1222. [CrossRef]

69. Zhang, B.; Kang, S.; Li, F.; Tong, L.; Du, T. Variation in vineyard evapotranspiration in an arid region of northwest China. Agric. Water Manag. 2010, 97, 1898-1904. [CrossRef] 
70. Wu, L.; Su, X.; Ma, X.; Kang, Y.; Jiang, Y. Integrated modeling framework for evaluating and predicting the water resources carrying capacity in a continental river basin of Northwest China. J. Clean. Prod. 2018, 204, 366-379. [CrossRef]

71. Yu, R.; Brillante, L.; Martínez-Lüscher, J.; Kurtural, S.K. Spatial Variability of Soil and Plant Water Status and Their Cascading Effects on Grapevine Physiology Are Linked to Berry and Wine Chemistry. Front. Plant Sci. 2020, 11, 790. [CrossRef] [PubMed]

72. Li, T.; Hao, X.; Kang, S. Spatiotemporal Variability of Soil Moisture as Affected by Soil Properties during Irrigation Cycles. Soil Sci. Soc. Am. J. 2014, 78, 598-608. [CrossRef]

73. Lü, D.; Gao, G.; Lü, Y.; Xiao, F.; Fu, B. Detailed land use transition quantification matters for smart land management in drylands: An in-depth analysis in Northwest China. Land Use Policy 2020, 90, 104356. [CrossRef]

74. Yu, Y.; Jia, Z.Q. Changes in soil organic carbon and nitrogen capacities of Salix cheilophila Schneid along a revegetation chronosequence in semi-arid degraded sandy land of the Gonghe Basin, Tibet Plateau. Solid Earth 2014, 5, 1045-1054. [CrossRef]

75. Zhou, Z.-Y.; Li, F.-R.; Chen, S.-K.; Zhang, H.-R.; Li, G. Dynamics of vegetation and soil carbon and nitrogen accumulation over 26 years under controlled grazing in a desert shrubland. Plant Soil 2010, 341, 257-268. [CrossRef]

76. Luo, G. Dragon System of Training and Pruning in China's Viticulture. Am. J. Enol. Vitic. 1986, 37, $152-157$.

77. Huang, H. Viticulture in China. Hort. Sci. 1980, 15, 461-466.

78. Pan, D.; Yang, J.; Zhou, G.; Kong, F. The influence of COVID-19 on agricultural economy and emergency mitigation measures in China: A text mining analysis. PLoS ONE 2020, 15, e0241167. [CrossRef]

79. Zhang, S.; Wang, S.; Yuan, L.; Liu, X.; Gong, B. The impact of epidemics on agricultural production and forecast of COVID-19. China Agric. Econ. Rev. 2020, 12, 409-425. [CrossRef]

80. Wang, R.; Sun, Q.; Chang, Q. Soil Types Effect on Grape and Wine Composition in Helan Mountain Area of Ningxia. PLoS ONE 2015, 10, e0116690. [CrossRef] [PubMed]

81. Lourenço-Gomes, L.; Pinto, L.M.C.; Rebelo, J. Wine and cultural heritage. The experience of the Alto Douro Wine Region. Wine Econ. Policy 2015, 4, 78-87. [CrossRef]

82. Rodrigo-Comino, J.; Wirtz, S.; Brevik, E.C.; Ruiz-Sinoga, J.D.; Ries, J.B. Assessment of agri-spillways as a soil erosion protection measure in Mediterranean sloping vineyards. J. Mt. Sci. 2017, 14, 1009-1022. [CrossRef]

83. Calleja-Cervantes, M.E.; Fernández-González, A.J.; Irigoyen, I.; Fernández-López, M.; Aparicio-Tejo, P.M.; Menéndez, S. Thirteen years of continued application of composted organic wastes in a vineyard modify soil quality characteristics. Soil Biol. Biochem. 2015, 90, 241-254. [CrossRef]

84. Coelho, G.F.; Gonçalves, A.C.; Nóvoa-Muñoz, J.C.; Fernández-Calviño, D.; Arias-Estévez, M.; Fernández-Sanjurjo, M.J.; Álvarez-Rodríguez, E.; Núñez-Delgado, A. Competitive and non-competitive cadmium, copper and lead sorption/desorption on wheat straw affecting sustainability in vineyards. J. Clean. Prod. 2016, 139, 1496-1503. [CrossRef]

85. Follain, S.; Ciampalini, R.; Crabit, A.; Coulouma, G.; Garnier, F. Effects of redistribution processes on rock fragment variability within a vineyard topsoil in Mediterranean France. Geomorphology 2012, 175-176, 45-53. [CrossRef]

86. Jomaa, S.; Barry, D.; Brovelli, A.; Heng, B.; Sander, G.; Parlange, J.-Y.; Rose, C. Rain splash soil erosion estimation in the presence of rock fragments. Catena 2012, 92, 38-48. [CrossRef]

87. Jomaa, S.; Barry, D.; Heng, B.; Brovelli, A.; Sander, G.; Parlange, J.-Y. Effect of antecedent conditions and fixed rock fragment coverage on soil erosion dynamics through multiple rainfall events. J. Hydrol. 2013, 484, 115-127. [CrossRef]

88. Serpa, D.; Nunes, J.; Keizer, J.; Abrantes, N. Impacts of climate and land use changes on the water quality of a small Mediterranean catchment with intensive viticulture. Environ. Pollut. 2017, 224, 454-465. [CrossRef]

89. Ramos, M.; Mulligan, M. Spatial modelling of the impact of climate variability on the annual soil moisture regime in a mechanized Mediterranean vineyard. J. Hydrol. 2005, 306, 287-301. [CrossRef]

90. Eijsackers, H.; Beneke, P.; Maboeta, M.; Louw, J.; Reinecke, A. The implications of copper fungicide usage in vineyards for earthworm activity and resulting sustainable soil quality. Ecotoxicol. Environ. Saf. 2005, 62, 99-111. [CrossRef]

91. Lieskovský, J.; Kenderessy, P. Modelling the Effect of Vegetation Cover and Different Tillage Practices on Soil Erosion in Vineyards: A Case Study in Vráble (Slovakia) Using Watem/Sedem. Land Degrad. Dev. 2012, 25, 288-296. [CrossRef]

92. Cerdà, A.; Ackermann, O.; Terol, E.; Rodrigo-Comino, J. Impact of Farmland Abandonment on Water Resources and Soil Conservation in Citrus Plantations in Eastern Spain. Water 2019, 11, 824. [CrossRef]

93. Ramos, M.; Martinez-Casasnovas, J.A. Impact of land levelling on soil moisture and runoff variability in vineyards under different rainfall distributions in a Mediterranean climate and its influence on crop productivity. J. Hydrol. 2006, 321, 131-146. [CrossRef]

94. Bagagiolo, G.; Biddoccu, M.; Rabino, D.; Cavallo, E. Effects of rows arrangement, soil management, and rainfall characteristics on water and soil losses in Italian sloping vineyards. Environ. Res. 2018, 166, 690-704. [CrossRef] [PubMed]

95. Martínez-Casasnovas, J.A.; Ramos, M.C.; García-Hernández, D. Effects of land-use changes in vegetation cover and sidewall erosion in a gully head of the Penedès region (Northeast Spain). Earth Surf. Process. Landf. 2009, 34, 1927-1937. [CrossRef]

96. Ruizcolmenero, M.; Bienes, R.; Eldridge, D.J.; Marques, M. Vegetation cover reduces erosion and enhances soil organic carbon in a vineyard in the central Spain. Catena 2013, 104, 153-160. [CrossRef]

97. Rodrigo-Comino, J.; Novara, A.; Gyasi-Agyei, Y.; Terol, E.; Cerdà, A. Effects of parent material on soil erosion within Mediterranean new vineyard plantations. Eng. Geol. 2018, 246, 255-261. [CrossRef]

98. Comino, J.R.; Quiquerez, A.; Follain, S.; Raclot, D.; Le Bissonnais, Y.; Casalí, J.; Giménez, R.; Cerdà, A.; Keesstra, S.-D.; Brevik, E.-C.; et al. Soil erosion in sloping vineyards assessed by using botanical indicators and sediment collectors in the Ruwer-Mosel valley. Agric. Ecosyst. Environ. 2016, 233, 158-170. [CrossRef] 
99. Assefa, E.; Hans-Rudolf, B.; Bork, H.-R. Farmers' Perception of Land Degradation and Traditional Knowledge in Southern Ethiopia-Resilience and Stability. Land Degrad. Dev. 2015, 27, 1552-1561. [CrossRef]

100. Carvalho, T.M.M.; Coelho, C.O.A.; Ferreira, A.J.D.; Charlton, C.A. Land Degradation Processes in Portugal: Farmers' Perceptions of the Application of European Agroforestry Programmes. Land Degrad. Dev. 2002, 13, 177-188. [CrossRef]

101. Crossland, M.; Winowiecki, L.A.; Pagella, T.; Hadgu, K.; Sinclair, F. Implications of variation in local perception of degradation and restoration processes for implementing land degradation neutrality. Environ. Dev. 2018, 28, 42-54. [CrossRef]

102. Cohen-Shacham, E.; Janzen, C.; Maginnis, S.; Walters, G. Nature-Based Solutions to Address Global Societal Challenges; IUCN Commission on Ecosystem Management (CEM): Gland, Switzerland; IUCN World Commission on Protected Areas (WCPA): Gland, Switzerland, 2016; p. 97. [CrossRef]

103. Nesshöver, C.; Assmuth, T.; Irvine, K.N.; Rusch, G.M.; Waylen, K.A.; Delbaere, B.; Haase, D.; Jones-Walters, L.; Keune, H.; Kovacs, E.; et al. The science, policy and practice of nature-based solutions: An interdisciplinary perspective. Sci. Total. Environ. 2017, 579, 1215-1227. [CrossRef] [PubMed]

104. Ben-Salem, N.; Álvarez, S.; López-Vicente, M. Soil and Water Conservation in Rainfed Vineyards with Common Sainfoin and Spontaneous Vegetation under Different Ground Conditions. Water 2018, 10, 1058. [CrossRef]

105. IUSS Working Group WRB. World Soil Resources Report, (World Reference Base for Soil Resources) 2014; FAO: Rome, Italy, 2014.

106. Rodrigo-Comino, J.; Keshavarzi, A.; Zeraatpisheh, M.; Gyasi-Agyei, Y.; Cerdà, A. Determining the best ISUM (Improved stock unearthing Method) sampling point number to model long-term soil transport and micro-topographical changes in vineyards. Comput. Electron. Agric. 2019, 159, 147-156. [CrossRef]

107. Da Silva, A.M.; Moradi, E.; Rodrigo-Comino, J.; Cerdà, A. Spatial variability of soil roughness in persimmon plantations: A new combined ISUM (improved stock unearthing method) approach. Ecol. Indic. 2019, 106, 105528. [CrossRef]

108. Marques, M.; Ruiz-Colmenero, M.; Bienes, R.; García-Díaz, A.; Sastre, B. Effects of a Permanent Soil Cover on Water Dynamics and Wine Characteristics in a Steep Vineyard in the Central Spain. Air Soil Water Res. 2020, 13. [CrossRef]

109. Bogunovic, I.; Telak, L.J.; Pereira, P. Experimental Comparison of Runoff Generation and Initial Soil Erosion Between Vineyards and Croplands of Eastern Croatia: A Case Study. Air Soil Water Res. 2020, 13. [CrossRef]

110. Iserloh, T.; Ries, J.B.; Cerdà, A.; Echeverría, M.T.; Fister, W.; Geissler, C.; Kuhn, N.J.; León, F.J.; Peters, P.; Schindewolf, M.; et al. Comparative Measurements with Seven Rainfall Simulators on Uniform Bare Fallow Land. Z. Geomorphol. Suppl. 2013, 57, 11-26. [CrossRef]

111. Panagos, P.; Katsoyiannis, A. Soil erosion modelling: The new challenges as the result of policy developments in Europe. Environ. Res. 2019, 172, 470-474. [CrossRef] [PubMed]

112. Incerti, G.; Feoli, E.; Salvati, L.; Brunetti, A.; Giovacchini, A. Analysis of bioclimatic time series and their neural network-based classification to characterise drought risk patterns in South Italy. Int. J. Biometeorol. 2007, 51, 253-263. [CrossRef] [PubMed]

113. Jasiewicz, J.; Metz, M. A new GRASS GIS toolkit for Hortonian analysis of drainage networks. Comput. Geosci. 2011, $37,1162-1173$. [CrossRef] 